\title{
Layered Crystals as Porous Materials: the Effect of Ultrasonic Treatment
}

\author{
B.A. Lukiyanets, D.V. Matulka \\ Lviv Polytechnic National University, 12, Bandera St., Lviv 79013, Ukraine
}

(Received 10 June 2020; revised manuscript received 15 February 2021; published online 25 February 2021)

\begin{abstract}
A layered crystal is a set of packets consisting of covalently interconnected several monoatomic planes. At the same time, neighboring packets interact with much weaker van der Waals forces. This is the reason for the sharply anisotropic nature of layered crystals, which allows to largely change their physical properties by such external factors as ultrasonic treatment or intercalation. Layered crystals can be considered as specific porous materials with van der Waals gaps as pores. The Kronig-Penney model was used to describe the changes in the properties of the layered crystal caused by these factors. Since it is experimentally established that such factors lead to the expansion of the layered crystal exclusively due to changes in the van der Waals gap, the proposed modeling was an analysis of the Kronig-Penney model with a change in the only geometric parameter of the crystal - the width of its van der Waals gap. The changes in the electronic spectrum caused by such a change were calculated, and on their basis, the manifestations in the quantum capacity of the layered crystal were analyzed.
\end{abstract}

Keywords: Layered crystals, Porous materials, Ultrasonic treatment, Quantum capacitance.

\section{INTRODUCTION}

Recently, an interest in porous materials, nanoscale compounds and compounds with the presence of nanoscale objects in them has been observed. The distinctive feature of the nanoscale crystal structures is their sizes of $\sim 1 \div 100 \mathrm{~nm}$ in at least one crystallographic direction which gives rise to tangible size quantization of the spectrum. As to compounds with nanoscale objects, the porous materials [1] can be considered as belonging to them, i.e. bulk materials with a set of nanoscale pores inside them or surrounding them. It is the pores that determine the physicochemical properties to a greater extent than the bulk of the porous material does.

Materials with pores of different sizes, shapes, and compositions have wide practical application, in particular as catalysts, cathode materials for highly efficient electric energy storage.

A wide class of quasi-two-dimensional crystalline structures - layered crystals - can be considered as special nanoporous materials. Any layered crystal is a set of monatomic layers or packets with covalent or ioncovalent bonds within them and with much weaker van der Waals interaction between them. The most widespread layered crystals are graphite, transition metal dichalcogenides $\mathrm{MX}_{2}(\mathrm{M}=\mathrm{Mo}, \mathrm{Ta}, \mathrm{Ti}, \mathrm{W}, \mathrm{Nb}, \mathrm{Sn}, \mathrm{Zr}, \mathrm{Hf}$, $\mathrm{V} ; \mathrm{X}=\mathrm{S}$, Se, $\mathrm{Te})$, compounds $\mathrm{A}_{3} \mathrm{~B}_{6}(\mathrm{~A}=\mathrm{Ga}, \mathrm{In} ; \mathrm{B}=\mathrm{S}$, $\mathrm{Se}, \mathrm{Te}$ ), and others. Fig. 1 shows a typical representative of layered crystals $\mathrm{MoS}_{2}$. It is a set of periodically arranged packets of monoatomic planes S-Mo-S. GaSe has a similar structure with Se-Ga-Ga-Se atomic planes. Important characteristics of the layered crystals are the thickness of the packet and the distance between adjacent packets (van der Waals gap). Thus, in $\mathrm{MoS}_{2}$ they are $3.241 \AA$ and $2.903 \AA$, respectively [2].

The existence of nanoscale regions with weak interaction in layered crystals permits the introduction of foreign atoms or organic and inorganic molecules into them, as well as the removal of foreign atoms or organic and inorganic molecules from them. These phenomena are called intercalation and deintercalation, respectively; and the foreign objects are called intercalates. Depending on the nature of the intercalates, on their surroundings in the van der Waals gap, on post-reaction treatment the interlayer distances can be varied from $0.1 \mathrm{~nm}$ (in intercalated $\mathrm{Li}^{+}$compounds) to more than $5 \mathrm{~nm}$, i.e. the degree of segregation of the layered crystal can be changed. It is experimentally established that in the case of non-interacting packets such a two-dimensionality has especially manifested itself in layered crystals. Thus, the solitary layer of $\mathrm{MoS}_{2}$ showed $\sim 10^{4}$-fold increase in the quantum yield of luminescence.

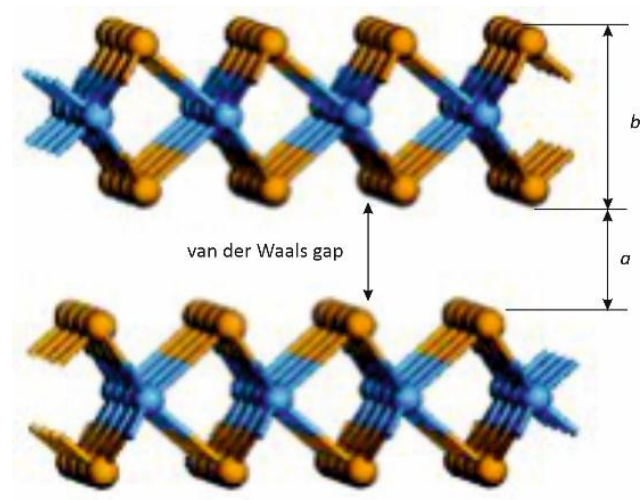

Fig. 1 - Layered crystals of $\mathrm{MoS}_{2}$ type

This phenomenon once again emphasizes the extraordinary nature of two-dimensionality unique properties priory discovered in the well-known monocrystalline graphitic films [3, 4].

Although layered crystals are not nanostructures, they can be identified with porous materials. In such crystals, the role of the pores is played by the strictly spatially ordered van der Waals gaps having the same widths. According to the characteristic sizes of the van der Waals gaps, with respect to the classification of porous crystals [5], layered crystals refer to mesoporous materials. Thus, the problems of layered crystals are closely intertwined with the problems of porous crystals.

Ultrasonic treatment is another active factor in the 
change of the van der Waals gap $[1,6,7]$. Variation in the physical characteristics of layered crystals or porous structures by means of intercalation or by ultrasonic treatment makes it possible to solve such an urgent scientific and technological problem as the creation of high-capacity electric energy storages, in particular, on the basis of sodium and potassium, unlike it is in lithium-ion energy storage [8].

Below we consider the manifestations of the change in the van der Waals gap of a layered crystal caused by ultrasonic treatment on the example of a quantum capacitance.

\section{ULTRASONIC TREATMENT OF LAYERED CRYSTALS}

The mechanism of ultrasonic treatment is not completely understood. However, the aforesaid increase in the thickness of the layered crystal along the normal to the layers due to the increase in van der Waals gaps caused by ultrasonic treatment (as well as by intercalation) is undoubtedly an important factor in the change of physical characteristics of the layered crystal.

Let us consider layered crystals as superstructures. In the general case, the electronic states in such a twocomponent structure $A, B$ with the lattice period $d=L_{A}+L_{B}\left(L_{A}, L_{B}\right.$ are thicknesses of the components $A, B$, respectively) are determined according to the transcendental equation [9]

$$
\cos k d=f(E),
$$

where $k$ is the quasi-momentum and $f(E)$ is a function that essentially depends on the shape of the potential inside the primitive cell.

We choose the widely used Kronig-Penney potential [10] for describing a layered crystal as a superstructure (see Fig. 1), in which $L_{A}=a$ is the interbarrier distance, $L_{B}=b$ is the thickness of the barrier. Note that, besides in the work [9], a similar model was used to investigate MQW structures [11], and the almost rectangular potential was satisfactory for the description of the change in the electric field of a double layer caused by ultrasonic treatment.

It is established that changes in the lattice period under the action of ultrasound or intercalation are due to the expansion of the van der Waals gap, since the thickness of the packet practically does not change [12].

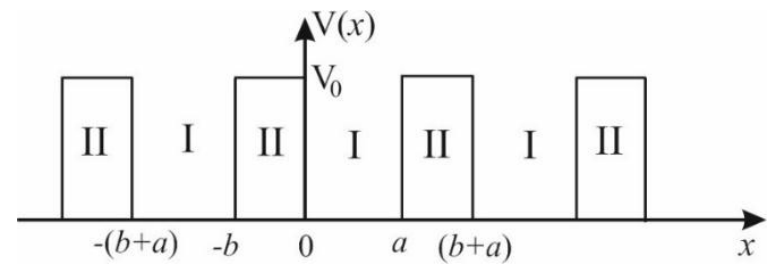

Fig. 2 - The Kronig-Penney potential

To ensure the effective action of ultrasonic waves in a solid, it is placed in a liquid medium. Therefore, the transmission of pressure created by ultrasound, according to Pascal's law, will be the same for any van der Waals gap; therefore, the changes in width of each of them will be the same. This is unlike the intercalation, where under certain conditions such changes can affect only certain van der Waals gaps [13].

It is known that the solution of the stationary Schrödinger equation for an ordered crystal system, namely of the equation

$$
\frac{d^{2} \psi(x)}{d x^{2}}+(E-V(x)) \psi(x)=0
$$

is the Bloch function

$$
\psi(x)=u(x) \exp (i k x)
$$

where $u(x)$ is the Bloch multiplier.

Substituting (3) into (2), we obtain a homogeneous differential equation with constant coefficients for the Bloch multiplier:

$$
\frac{d^{2} u_{s}}{d x^{2}}+2 i k \frac{d u_{s}}{d x}-\left(k^{2}-\beta_{i}^{2}\right) u_{s}=0 .
$$

Its solutions are the following:

$$
\begin{aligned}
& u_{1}(x)=A_{1} \exp \left(i\left(\beta_{1}-k\right) x\right)+B_{1} \exp \left(-i\left(\beta_{1}+k\right) x\right),(4) \\
& u_{2}(x)=A_{2} \exp \left(i\left(\beta_{2}-k\right) x\right)+B_{2} \exp \left(-i\left(\beta_{2}+k\right) x\right),(5)
\end{aligned}
$$

where $\beta_{1} \equiv \alpha=\sqrt{\frac{2 m \mathrm{E}}{\hbar^{2}}}$ and $\beta_{2} \equiv \beta=\sqrt{\frac{2 m\left(E-V_{0}\right)}{\hbar^{2}}}$.

The unknowns $A_{1}, B_{1}, A_{2}, B_{2}$ in expressions (4), (5) can be determined from the condition of continuity and the condition of smoothness of the envelope at the „barrier-well" boundary and from its periodicity with the period $d=a+b$. In this case, the non-trivial solution of the obtained system of linear equations in $A_{1}, B_{1}, A_{2}, B_{2}$ is possible if the determinant whose entries are the coefficients of unknowns $A_{1}, B_{1}, A_{2}, B_{2}$ is equal to zero. The expansion of such a determinant leads to the equation

$$
\cos k(a+b)=-\frac{a^{2}+\beta^{2}}{2 \alpha \beta} \sin \alpha a \cdot \sin \beta b+\cos \alpha a \cdot \cos \beta b,
$$

i.e. the latter coincides with equation (1) in which $f(E)$ has a specific expression.

The transcendental equation (6) has been solved by us using Maple, Mathematica, and Fortran software packages to search for graphical intersections of the left and right sides of such an equation [10]. The set of allowed zones, separated by gaps at the points $k_{x}=0$ and $k_{x}= \pm \pi / d$, has been finally obtained [10]:

$$
E_{j}\left(k_{x}\right)=E_{j \min }\left(k_{x}\right)+\frac{\Delta_{j}}{2}\left[1+(-1)^{j} \cos \left(k_{x} d\right)\right],
$$

where $j$ is the number of the zone, $E_{j \min }\left(k_{x}\right)$ is its bottom, $\Delta_{j}=E_{j \max }-E_{j \min }$ is the width of the $j$-th allowed zone with the cosine dispersion law (here $k_{x}=n / L_{x}$; $L_{x}=N_{x} d$ is the main region of the crystal, $n \in 0,1,2 \ldots\left(N_{x}-1\right)$.

\section{CALCULATION OF THE QUANTUM CAPACITANCE OF LAYERED CRYSTALS}

In general case, the electrical capacitance of the conductor $C$ is determined from the equality 


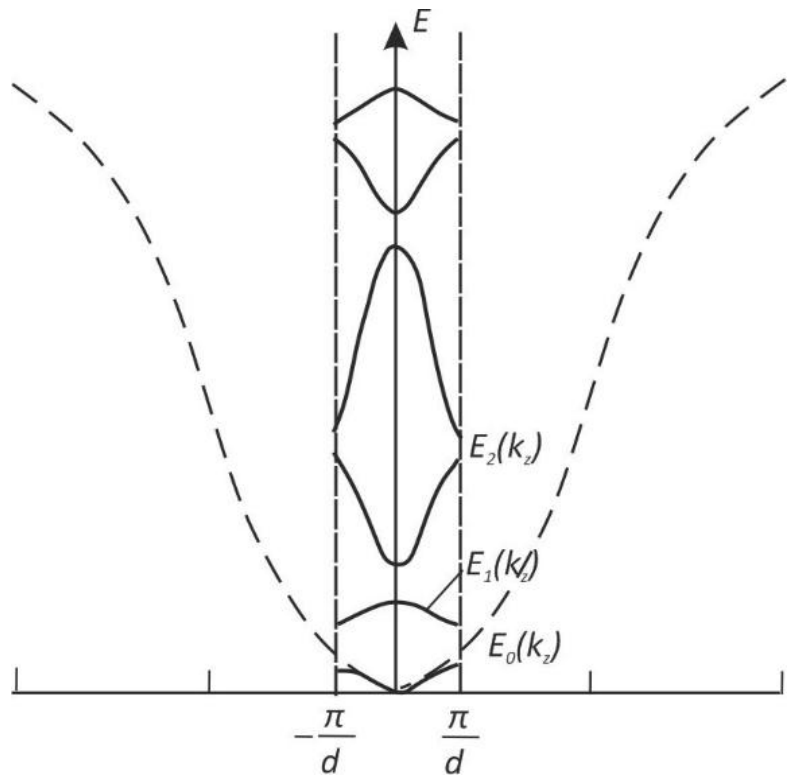

Fig. 3 - Parabolic dispersion (dashed curve) splitted up by the Kronig-Penney potential

$$
\frac{1}{C}=\frac{1}{C_{e l}}+\frac{1}{C_{q}},
$$

where $C_{e l}$ and $C_{q}$ are the capacitances of the classical and quantum capacitors connected in serials, respectively. Classical capacitance is electrostatic in its nature, whereas quantum capacitance is due to the filling of electronic states [15]. As a rule, $C_{q} \gg C_{e l}$, therefore $C \approx C_{e l}$, i.e. $C_{q}$ is ineffective. However, the situation in nano-objects can be opposite.

Therefore, interest in the phenomenon of quantum capacitance has increased sharply lately. Recently [16], the first successful experimental measurement of quantum capacitance in a currently popular object such as graphene has been reported. The authors believe that quantum capacitance is as important characteristic as the most popular today characteristic, namely electron mobility $\mu$, is.

In the general case, quantum capacitance $C_{q}$ of a system is defined as

$$
C_{q}=-\frac{d Q}{d \mu} \Rightarrow-e \frac{d}{d \mu} \sum_{n} f\left(E_{n}\right)
$$

i.e. as the change in charge $Q$ caused by the change in the chemical potential $\mu$.

Here

$$
f\left(E_{n}\right)=\frac{1}{\exp \left(\frac{E_{n}-\mu}{k T}\right)+1}
$$

is the Fermi-Dirac distribution. The summation in (8) is over all quantum states $E_{n}$ of the system.

In our case, taking into account the quantum states (7), we have

$$
C_{q}=\frac{e}{4 k T} \cdot 2 \cdot \sum_{n=0}^{N_{x}-1} \sum_{j} c h^{-2}\left(\frac{E_{j}(n)-\mu}{2 k T}\right),
$$

where $e$ is the absolute value of the electron charge.

\section{ANALYSIS OF RESULTS. CONCLUSIONS}

Consider $C_{q}(\mu)$ calculated for fixed values of the packet width $b(b=0.8 \mathrm{~nm})$ and the barrier height $V_{0}$ $\left(V_{0}=1.2 \mathrm{eV}\right)$ at temperatures $T=100$ and $200 \mathrm{~K}$ for the well widths $a=0.2,0.4,0.6,0.8 \mathrm{~nm}$ caused by ultrasonic treatment.

Substituting the values (obtained from the graphical solution of the transcendental equation (6)) of the energy states (7) into (9), we obtain the dependences $C_{q}(\mu)$ shown in Fig. 4. Here the shaded areas are allowed zones.

It can be seen that energy states $E_{j}\left(k_{x}\right)$ are a set of non-overlapping zones. At energies $E<V_{0}$, such zones are the result of tunneling, and therefore, with the increase in energy the widths of such zones increase, while the widths of the forbidden ones decrease. At energies above the barrier height, i.e. for $E>V_{0}$, gaps that disappear with increasing energy still occur. Such zones are the result of interference effects. Fig. 4 shows the following:

the curve $C_{q}(\mu)$ is a manifestation of dimensional quantization;

correlation of $C_{q}(\mu)$ dependence with the location of the allowed zones;

the value of the $C_{q}(\mu)$ peaks decreases with increasing $\mu$. Since $C_{q}$ is closely related with the density of states, a qualitative explanation concerning the decrease can be obtained from the fact that the density of states in one-dimensional crystals with a parabolic dispersion law has a similar dependence $\left(\sim 1 / E^{1 / 2}\right)$. It can be explained by the fact that the maximum peak values are greater for electrons with smaller well widths. A qualitative picture of the increase in the capacitance of carbon electrodes with the decrease in their pores was also observed in work [17]. The curve of $C_{q}(\mu)$ differs sharply from the curve, which we have in the case of a similar one-dimensional problem with an infinitely deep potential well [17], i.e. in the Kronig-Penney model under the absence of tunneling. In the latter case, the electron spectrum is a set of discrete levels and, as a consequence, the curve of $C_{q}(\mu)$ has the structure of strongly expressed peaks. In our case, the complex structure of the peaks is a consequence of the blurring of levels by the tunneling effect.

From the analysis of Fig. 4, it follows that the peaks of $C_{q}(\mu)$ become higher and more blurry as they move to higher temperatures. 

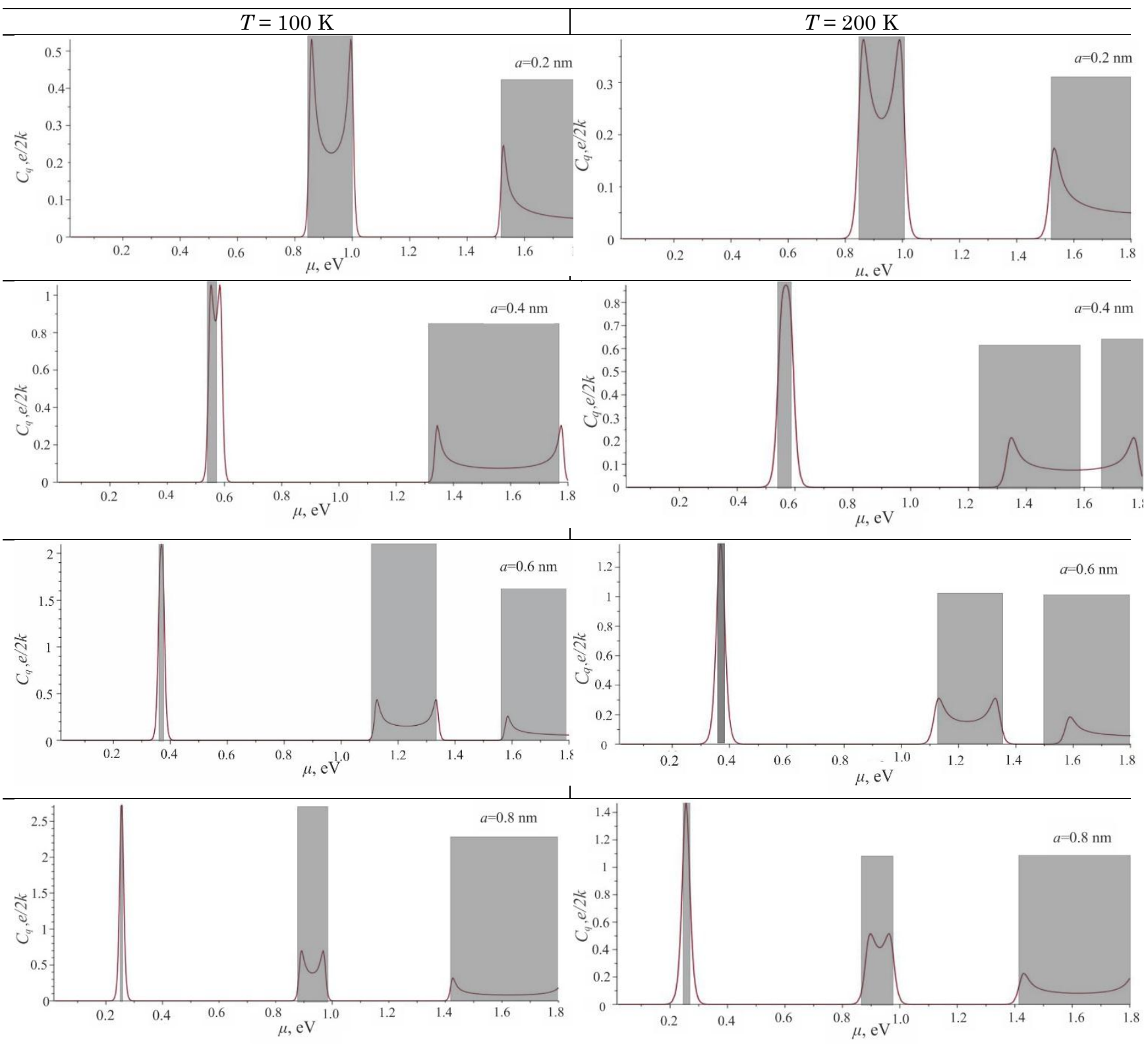

Fig. 4 - Dependence of quantum capacitance $C_{q}(\mu)$ at temperatures of $100 \mathrm{~K}$ and $200 \mathrm{~K}$ at the well widths $a=0.2,0.4,0.6,0.8 \mathrm{~nm}$

\section{REFERENCES}

1. Nanoparticles Materials. In: Handbook of Nanophysics. Functional Nanomaterials. Edited by Klaus. D. Sattler. (CRS Press, 2011)

2. J.A. Stewart, D.E. Spearot, Modell. Simul. Mater. Sci. Eng. 21, 045003 (2013).

3. K.S. Novoselov, A.K. Geim, S.V. Morozov, D. Jiang, Y. Zhang S.V. Dubonos, I.V. Grigorieva, A.A. Firsov, Science 306, 666 (2004).

4. A.H.C. Neto, F. Guinea, N.M.R. Peres, K.S. Novoselov, A.K. Geim, Rev. Mod. Phys. 81, 109, (2009).

5. S. Lowell, J.E. Shields, M.A. Thomas, M. Thommes, Characterization of Porous Solids and Powders. Surface Area. Pore Size and Density (The Netherlands: Kluwer) (2004).

6. O.V. Balaban, I.I. Hryhorchak, A.I. Kondyr, Mater. Sci. 50, 109 (2014).

7. O.V. Balaban, I.I. Grygorchak, R.M. Peleshchak, O. Kuzyk, O.O. Dankiv, Prog. Nat. Sci.: Mater. Int. 24, 397 (2014).
8. Y. Jung, Y. Zhou, J.J. Cha, J. Inorg. Chem. Front. 3, 453 (2016).

9. P.Y. Yu, M. Cardona, Fundamentals of Semiconductors Physics and Materials Properties, 4th Edition (Berlin Heidelberg: Springer: 2010).

10. C. Kittel, Introduction to Solid State Physics, 8th Edition (New York: J. Willey \& Sons: 2004).

11. Y. Zhang, Y. Wang, J. Modern Phys. 4, 568 (2013).

12. L.A. Chernozatonskii, A.A. Artyukh, Phys.-Usp. 61, 2 (2018).

13. M. Chandesris, D. Caliste, D. Jamet, P. Pochet, J. Phys. Chem. C 123, 38 (2019).

14. A.P. Silin, Phys.-Usp. 28, 972 (1985).

15. R. Tsu, Superlattice to Nanoelectronics, 2nd Edition (Elsevier: 2011)

16. J. Xia, F. Chen, J. Li, N. Tao, Nat. Nanotechnol. 4, 505 (2009).

17. D.V. Matulka, B.A. Lukiyanets, Phys. Chem. Solid State 4, 1 (2011) [In Ukrainian]. 


\title{
Шаруваті кристали як пористі матеріали: вплив ультразвукової обробки
}

\author{
Б.А. Лукіянець, Д.В. Матулка
}

Національний університет «Львівська політехніка», вул. С. Бандери, 12, Львів 79013, Україна

Шаруватий кристал е набором пакетів, що складаються з ковалентно зв'язаних між собою декількох моноатомних площин. Сусідні пакети взаємодіють між собою надто слабими ван дер ваальсовими силами, що і є причиною різкої анізотропії шаруватих кристалів. Така анізотропія породжує можливості в широких межах міняти фрізичні властивості шаруватих кристалів такими зовнішніми фракторами як УЗ-обробка чи інтеркаляція. Шаруваті кристали можна розглядати як специфічні поруваті матеріали з ван дер ваальсовими щілинами в якості пор. Для опису змін властивостей шаруватого кристалу, спричиненого дією зазначених факторів, була використана модель Кроніга-Пенні. Оскільки експериментально встановлено, що такі фрактори призводять до розширення шаруватого кристалу виключно за рахунок змін ван дер ваальсових щілин, то пропоноване в роботі моделювання - це аналіз моделі Кроніга-Пенні зі зміною в ній єдиного геометричного параметра кристалу - ширини його ван дер ваальсової щілини. Були розраховані зміни електронного спектру, спричинені такою зміною, а на їх основі проаналізовані прояви в квантовій емності шаруватого кристалу.

Ключові слова: Шаруваті кристали, Пористі матеріали, Ультразвукова обробка, Квантова ємність. 